\title{
HUBUNGAN PERILAKU PENJAMAH DENGAN KEBARADAAN MPN COLIFORM PADA MINUMAN DI ANGKRINGAN KABUPATEN BARRU Rostina $^{1}$ dan Rosita Mutiana ${ }^{2}$ \\ ${ }^{1.2}$ Poltekkes Kemenkes Makassar rositamutiana96@gmail.com
}

\begin{abstract}
Fruit juice is one type of beverage sold in place and processed without heating process, the processing is not sanitary is very instrumental to make this beverage contains bacteria MPN Coliform. The purpose of this study is to determine the relationship between the behavior of the handler with the presence of MPN Coliform on drinks At The Barru Regency Place. The research design in this research is cross-sectional. A total sample of 20 drink samples and 20 respondents, the sample was chosen by purposive sampling. The behavioral data of the handlers were obtained through direct observation based on the observation questionnaire, while the present data was coliform obtained using MPN coliform. Data were analyzed by correlation Fisher. The statistical test shows that the knowledge variable $(p=1,000)$ and attitude variable $(p=0.373)$ are greater than $p>0,05$, so H0 is accepted. Meanwhile, the action variable $(\mathrm{p}=0,000)$ is smaller than $p<0.05$, so Ha is accepted. The results of the study there are 18 samples from 20 samples which studied contain coliform with $>20$ colonies/ ml. This result exceeds the maximum limit determined by the SNI of 2009 that the maximum limit of Coliform in the juice is $2 \times 101$ colony/ml. This is influenced by the location of sales, temperature, humidity, the action of handlers, raw materials and equipment. This research concludes that the presence of MPN Coliform in beverages is not related to knowledge and attitude, but related to the action of handlers at The Place.
\end{abstract}

Keywords: Food Handlers, MPN Coliform

\section{ABSTRAK}

Jus buah merupakan salah satu jenis minuman yang dijual di Angkringan dan diolah tanpa proses pemanasan, pengolahan yang tidak saniter sangat berperan membuat minuman ini mengandung bakteri MPN Colform.Tujuan penelitian ini adalah untuk mengetahui hubungan antara perilaku penjamah dengan keberadaan MPN Coliform pada minuman di Angkringan Kabupaten Barru. Rancangan penelitian pada penelitian ini adalah cross-sectional. Jumlah sampel 20 sampel minuman dan 20 responden, sampel dipilih secara purposive sampling. Data perilaku penjamah diperoleh melalui pengamatan secara langsung berdasarkan kuesioner pengamatan, sedangkan data keberadaan coliform diperoleh menggunakan MPN coliform. Data dianalisis dengan korelasi Fisher. Uji statistik menunjukkan bahwa variabel pengetahuan $(p=1,000)$ dan variabel sikap $(p=0,373)$ yang lebih besar nilainya dari $p>0,05$, sehingga H0 diterima. Sedangkan, variabel tindakan $(p=0,000)$ yang lebih kecil dari $p<0,05$, sehingga Ha diterima. Hasil penelitian terdapat 18 sampel dari 20 sampel yang diteliti mengandung MPN Coliform dengan jumlah $>20 \mathrm{koloni} / \mathrm{ml}$. Hasil ini, melebihi batas maksimum yang ditentukan oleh SNI tahun 2009 bahwa batas maksimum MPN Coliform dalam sari buah sebanyak $2 \times 10^{1} \mathrm{koloni} / \mathrm{ml}$. Hal ini dipengaruhi oleh lokasi penjualan, suhu, kelembaban, tindakan penjamah, bahan baku dan peralatan. Kesimpulan dari penelitian ini adalah keberadaan MPN Coliform pada minuman tidak berhubungan dengan pengetahuan dan sikap, tetapi berhubungan dengan tindakan penjamah di Angkringan. Untuk itu diharapkan bagi penjual sebaiknya melakukan perilaku hidup bersih dan sehat.

Kata kunci :Perilaku Penjamah, MPN Coliform.

\section{PENDAHULUAN}

Minuman olahan tanpa kemasan dan tanpa merek adalah minuman yang dibuat oleh penjual setelah pembeli memesan minuman tersebut (Santoso, 2011). Minuman saat ini banyak yang terkontaminasi oleh mikroorganisme. Risiko besar untuk terjadinya kontaminasi minuman ada pada penjamah minuman. Pengetahuan, sikap dan tindakan penjamah mempengaruhi kualitas minuman yang dihasilkan.

Bakteri Coliform merupakan salah satu organisme yang digunakan sebagai indikator tercemarnya air atau makanan karena keberadaannya merupakan indikasi terjadinya kontaminasi oleh bakteri patogen (Chandra, 2007). Sesuai dengan peraturan Standar Nasional Indonesia (SNI) tahun 2009 tentang batas maksimum cemaran mikroba dalam pangan menyatakan bahwa kadar maksimum Coliform dalam sari buah $2 \times 10^{1} \mathrm{koloni} / \mathrm{ml}$. Salah satu kontaminasi minuman yang bisa disebabkan oleh Coliform yaitu Diare. Berdasarkan data penyakit yang diperoleh dari Badan Pusat Statistik (BPS, 2017) diperoleh jumlah kasus diare di Sulawesi Selatan pada tahun 2017 yaitu 192.681 kasus dan jumlah diare di kabupaten Barru tahun 2017 yaitu 2.896 kasus.

Menurut Peraturan Menteri Kesehatan Republik Indonesia nomor 942/MENKES/SK/VII/2003 tentang pedoman persyaratan hygiene sanitasi makanan jajanan menyatakan bahwa penjamah makanan jajanan dalam melakukan kegiatan pelayanan penanganan makanan jajanan harus memenuhi persyaratan antara lain tidak menderita penyakit mudah menular (batuk, pilek, influenza, diare, penyakit perut sejenisnya), menutup luka (pada luka terbuka/bisul atau luka lainnya), menjaga kebersihan tangan, rambut, kuku, dan pakaian, memakai celemek dan tutup kepala, mencuci 
Jurnal Sulolipu : Media Komunikasi Sivitas Akademika dan Masyarakat

Vol. 18 No 22018

e-issn : 2622-6960, p-issn : 0854-624X

tangan setiap kali hendak menangani makanan, menjamah makanan harus memakai alat/ perlengkapan, atau dengan alas tangan, tidak sambil merokok, menggaruk anggota badan (telinga, hidung, mulut atau bagian lainnya), serta tidak batuk atau bersin di hadapan makanan jajanan yang disajikan dan atau tanpa menutup mulut atau hidung.

Sementara berdasarkan hasil observasi awal di Angkringan kabupaten Barru ditemukan ada beberapa perilaku penjamah yang bertentangan peraturan tersebut seperti tidak mencuci tangan, tidak membersihkan tempat pengolahan sebelum mengolah, tidak menggunakan alat pelindung, dan sebagainya. Perilaku penjamah yang tidak memenuhi syarat sudah dipastikan minuman yang dijual pada angkringan tersebut kualitasnya tidak memenuhi syarat kesehatan. Salah satu jenis minumannya yaitu jus buah. Minuman ini diolah tanpa proses pemasakan/ pemanasan, pengolahan yang tidak saniter Coliform.

Berdasarkan permasalahan diatas maka penulis ingin melakukan penelitian mengenai "Hubungan Perilaku Penjamah Dengan Keberadaan MPN Coliform Pada Minuman Di Angkringan Kabupaten Barru"

\section{BAHAN DAN METODE}

\section{Lokasi Penelitian:}

Lokasi pengambilan sampel minuman dilakukan di Angkringan Jl. Merdeka Padongko, kelurahan Mangempang, kecamatan Barru, kabupaten Barru. Lokasi untuk pemeriksaan kandungan bakteriologis di Laboratorium Mikrobiologi Jurusan Kesehatan Lingkungan Politeknik Kesehatan Makassar.

\section{Desain dan Variabel Penelitian}

Penelitian ini merupakan penelitian survei analitik dengan rancangan cross sectional dimana variabel bebas dan variabel terikat diukur secara bersamaan guna mengetahui hubungan antara variabel-variabel tersebut.

Adapun variabel penelitian pada penelitian ini terdiri dari 3 variabel yaitu variabel bebas terdiri dari pengetahuan, sikap dan tindakan di Angkringan kabupaten Barru. Variabel terikat terdiri dari keberadaan MPN Coliform pada minuman, serta variabel pengganggu terdiri dari kondisi sanitasi tempat pengolahan,dan peralatan.

\section{Populasi dan Sampel}

Populasi dalam penelitian ini adalah semua pedagang minuman yang ada di Angkringan kabupaten Barru yaitu 50 pedagang.

Sampel yang akan diambil dalam penelitian ini adalah pedagang yang ada di Angkringan kabupaten Barru. Pada masing-masing sampel, yang diambil sebagai unit sampel adalah 20 orang dan 20 sampel minuman (jus avokad).

\section{Pengumpulan data}

Sumber data terdiri dari 2 yaitu data primer yang diambil secara langsung oleh peneliti dan data sekunder yang diperoleh dari sumber lain seperti, laporan pemerintah, buku, jurnal, dan karya tulis ilmiah. Pengumpulan data dilakukan dengan menggunakan metode observasi dan wawancara dengan menggunakan lembar observasi atau kuesioner.

5. Analisa Data (Jika memakai program statistic, tuliskan uji utama apa yang digunakan)

Analisis univariate dilakukan untuk mendeskripsikan variabel bebas yaitu: perilaku penjamah (pengetahuan, sikap dan tindakan).

Analisis bivariate dilakukan terhadap dua variabel yang diduga berhubungan. Analisis ini menggunakan uji statistik dengan program Statistic Product and Service Solutions (SPSS) berupa uji fisher exact test (Soekidjo, 2012).

\section{HASIL}

Adapun hasil pengujian hubungan antara pengetahuan dengan keberadaan MPN Coliform pada minuman, sebagai berikut:

\section{Hubungan Pengetahuan dengan Keberadaan MPN Coliform}

Tabel 1

Pengetahuan Responden tentang Pengolahan Minuman di Angkringan Kabupaten Barru

\begin{tabular}{ccc}
\hline Pengetahuan & Frekuensi & Persentase (\%) \\
\hline Baik & 13 & $65 \%$ \\
Cukup & 7 & $35 \%$ \\
Kurang & 0 & $0 \%$
\end{tabular}


Jurnal Sulolipu : Media Komunikasi Sivitas Akademika dan Masyarakat

Vol. 18 No 22018

e-issn : 2622-6960, p-issn : 0854-624X

\begin{tabular}{|c|c|c|c|c|c|c|c|}
\hline \multicolumn{8}{|c|}{$\begin{array}{c}\text { Tabel } 2 \\
\text { Hubungan Pengetahuan dengan Keberadaan } \\
\text { MPN Coliform Pada Minuman di Angkringan } \\
\text { Kabupaten Barru }\end{array}$} \\
\hline \multirow{3}{*}{$\begin{array}{c}\text { Pengetahu } \\
\text { an }\end{array}$} & \multicolumn{4}{|c|}{$\begin{array}{c}\text { Keberdaan MPN } \\
\text { Coliform }\end{array}$} & \multirow{2}{*}{\multicolumn{2}{|c|}{ Total }} & \multirow[t]{3}{*}{$P$} \\
\hline & & $\mathbf{S}$ & & MS & & & \\
\hline & $\mathbf{n}$ & $\%$ & $\mathbf{n}$ & $\%$ & $\mathbf{N}$ & $\%$ & \\
\hline \multirow[t]{2}{*}{ Baik } & 8 & 40 & 5 & 25 & 1 & 65 & \\
\hline & & $\%$ & & $\%$ & 3 & $\%$ & 1,00 \\
\hline Cukup & 4 & $\begin{array}{l}20 \\
\%\end{array}$ & 3 & $\begin{array}{l}15 \\
\%\end{array}$ & 7 & $35 \%$ & 0 \\
\hline Kurang & 0 & 0 & 0 & 0 & 0 & 0 & \\
\hline \multirow[t]{2}{*}{ Total } & 1 & 60 & 8 & 40 & 2 & 100 & \\
\hline & 2 & $\%$ & & $\%$ & 0 & $\%$ & \\
\hline
\end{tabular}

Sumber : Data Primer, 2018

Adapun hasil pengujian hubungan antara tindakan dengan keberadaan MPN Coliform pada minuman, sebagai berikut:

1. Hubungan tindakan dengan keberadaan MPN Coliform

Tabel 5

Tindakan Responden terhadap Pengolahan Minuman di Angkringan Kabupaten Barru Tindakan Frekuensi Persentase (\%)

\begin{tabular}{ccc}
\hline Baik & 7 & $35 \%$ \\
Kurang & 13 & $65 \%$ \\
\hline Total & 20 & $100 \%$
\end{tabular}

\section{Sumber : Data Primer, 2018}

Adapun hasil pengujian hubungan antara sikap dengan keberadaan MPN Coliform pada minuman, sebagai berikut:

1. Hubungan sikap dengan keberadaan MPN Coliform

Tabel 3

Sikap Responden terhadap Pengolahan

Minuman di Angkringan Kabupaten Barru

Sikap Frekuensi Persentase

(\%)

\begin{tabular}{ccc}
\hline Baik & 12 & $60 \%$ \\
Cukup & 8 & $40 \%$ \\
Kurang & 0 & $0 \%$ \\
\hline Total & 20 & $100 \%$
\end{tabular}

Sumber : Data Primer, 2018

Tabel 4

Hubungan Sikap dengan Keberadaan MPN

Coliform Pada Minuman di Angkringan

Kabupaten Barru

\begin{tabular}{cccccccc}
\hline Sikap & \multicolumn{4}{c}{ Keberdaan MPN } & \multicolumn{2}{c}{ Coliform } & \multicolumn{2}{c}{ Total } & $\boldsymbol{P}$ \\
& \multicolumn{2}{c}{ MS } & TMS & TM & & \\
& $\mathbf{n}$ & $\%$ & $\mathbf{n}$ & $\%$ & $\mathbf{N}$ & $\%$ & \\
\hline Baik & 7 & 35 & 5 & 25 & 12 & $60 \%$ & \\
& & $\%$ & & $\%$ & & & 0,373 \\
Cukup & 5 & 25 & 3 & 15 & 8 & $40 \%$ & \\
& & $\%$ & & $\%$ & & & \\
Kurang & 0 & 0 & 0 & 0 & 0 & 0 & \\
\hline Total & $\mathbf{1 2}$ & $\mathbf{6 0} \%$ & $\mathbf{8}$ & $\mathbf{4 0 \%}$ & $\mathbf{2 0}$ & $\mathbf{1 0 0} \%$ & \\
\hline
\end{tabular}

Sumber : Data Primer, 2018

Tabel 6

Hubungan Tindakan dengan Keberadaan MPN Coliform Pada Minuman di Angkringan Kabupaten Barru

\begin{tabular}{cccccccc}
\hline \multirow{2}{*}{$\begin{array}{c}\text { Tindaka } \\
\mathbf{n}\end{array}$} & \multicolumn{4}{c}{ Keberdaan $\mathbf{c}$ Coliform } & \multicolumn{2}{c}{ Total } & $\boldsymbol{P}$ \\
& $\mathbf{n}$ & $\%$ & $\mathbf{n}$ & $\%$ & $\mathbf{N}$ & $\%$ & \\
\hline Baik & 4 & 20 & 3 & 15 & 7 & $35 \%$ & \\
& & $\%$ & & $\%$ & & & 0,00 \\
Kurang & 8 & 40 & 5 & 25 & 1 & $65 \%$ & 0 \\
& & $\%$ & & $\%$ & 3 & & \\
\hline Total & $\mathbf{1}$ & $\mathbf{6 0}$ & $\mathbf{8}$ & $\mathbf{4 0}$ & $\mathbf{2}$ & $\mathbf{1 0 0}$ & \\
& $\mathbf{2}$ & $\%$ & & $\%$ & $\mathbf{0}$ & $\%$ & \\
\hline
\end{tabular}

Sumber : Data Primer, 2018

\section{PEMBAHASAN}

\section{Hubungan}

Keberadaan MPN Coliform

Berdasarkan hasil penelitian diketahui bahwa tidak ada hubungan antara pengetahuan penjamah dengan keberadaan MPN Coliform pada minuman yang dijual di Angkringan kabupaten Barru. Hasil ini didasarkan pada uji fisher diperoleh nilai $p$ value $1,000(P>0,05)$.

Pengetahuan merupakan hasil dari tahu, dan hal ini terjadi setelah seseorang melakukan penginderaan terhadap suatu objek tertentu. Tanpa pengetahuan seseorang tidak mempunyai dasar untuk mengambil keputusan dan menentukan tindakan terhadap masalah yang dihadapi, dimana apabila pengetahuan tinggi maka sikap dan tindakan seseorang juga akan baik, begitupun sebaliknya (Soekidjo, 2010).

Kategori pengetahuan mengenai cara mengolah minuman yang baik pada penjamah yang paling banyak adalah kategori baik (65\%) 
Jurnal Sulolipu : Media Komunikasi Sivitas Akademika dan Masyarakat

Vol. 18 No 22018

e-issn : 2622-6960, p-issn : 0854-624X

dengan persentase $67 \%-86 \%$, sedangkan (35\%) memiliki pengetahuan cukup dengan persentase $57 \%-62 \%$. Berdasarkan hasil penelitian yang dilakukan oleh Emida Lusiani Br Meliala (2017) terhadap 8 penjamah makanan (foodhandler) di Retreat center Sumakmur diperoleh hasil sebanyak 6 (75\%) responden yang tingkat pengetahuannya baik, dan sebanyak 2 (25\%) responden dikategorikan cukup. Adapun hasil penelitian yang telah dilakukan oleh Ummu Khairawaty.S (2013) terhadap 7 responden, tingkat pengetahuan penjamah makanan di Sekolah Dasar wilayah Kelurahan Mangasa Kec. Tamalate Kota Makassar, memiliki tingkat pengetahuan $(100 \%)$ yang sedang dengan persentase antara $42,86 \%-66,67 \%$.

Pengetahuan dapat dipengaruhi dari umur responden. Umur responden sebagian besar $(50 \%)$ memiliki rentang usia $26-45$ tahun. Kategori umur diatas 25 tahun terbagi menjadi 2 kategori, yaitu dewasa dengan umur 26 - 45 tahun dan umur 46 - 65 tahun termasuk dalam kategori lanjut usia (Depkes, 2009). Bertambahnya umur seseorang dapat berpengaruh pada peningkatan pengetahuan yang diperoleh pada umur tertentu atau menjelang usia lanjut tingkat pengetahuan sesorang berkurang (Amalia, 2016). Usia dewasa dirasa cukup untuk memiliki pengetahuan yang baik mengenai personal hygiene. Namun, disisi lain usia yang semakin bertambah dapat menyebabkan responden melupakan hal-hal penting dalam personal hygiene sehingga risiko kontaminasi pada produksi minuman sulit dihindari.

Tingkat pendidikan juga dapat menjadi faktor yang mempengaruhi pengetahuan seseorang. Tingkat pendidikan responden yang terbanyak adalah SMA dengan persentase 50\%. Tingkat pendidikan SMA merupakan salah satu tingkat pendidikan yang cukup tinggi dan hasil analisa data menunjukkan bahwa semua penjamah dengan pendidikan SMA termasuk kategori baik. Lama bekerja juga bisa menjadi faktor yang mempengaruhi pengetahuan. Pengetahuan dapat diperoleh dari pengalaman langsung atau melalui pengalaman orang lain dan dapat ditingkatkan melalui penyuluhan, baik secara individu maupun kelompok (Notoatmodjo, 2003). Rata - rata responden di teliti memiliki durasi kerja 1-5 tahun.

Berdasarkan Budiman (2013), tingkat pengetahuan dipengaruhi oleh tingkat pendidikan, informasi, dan lama kerja. Hal ini sesuai dengan teori Soekidjo (2010), yang mengatakan bahwa pengetahuan bisa diperoleh dengan cara tradisional seperti cara coba-salah, secara kebetulan, secara kekuasaan atau otoriter, pengelaman pribadi, cara akal sehat. Sedangkan cara modern melalui metodologi penelitian.

Penambahan pengetahuan bisa melalui kursus, pelatihan, penyegaran tentang sanitasi dan hygiene perorangan, karena yang diperlukan adalah keterampilan, karena pengetahuan dapat diperoleh dari penginderaan terhadap suatu objek (Soekidjo, 2010).

\section{Hubungan Sikap dengan Keberadaan MPN Coliform}

Berdasarkan hasil penelitian diketahui bahwa tidak ada hubungan antara sikap penjamah dengan keberadaan MPN Coliform pada minuman yang dijual di Angkringan kabupaten Barru. Hasil ini didasarkan pada uji fisher diperoleh nilai $p$ value $0,373(P>0,05)$.

Sikap merupakan kelanjutan dari pengetahuan yang diterapkan oleh seseorang. Sikap belum merupakan tindakan atau aktivitas melainkan hanya kesediaan dan kesiapan untuk melakukan suatu tindakan. Sikap membuat seseorang memakai atau tidak memakai sesuatu, sikap positif terhadap nilai-nilai tertentu tidak selalu terwujud dalam suatu tindakan nyata. Sikap hygiene dan sanitasi makanan terbatas pada penilaian dalam diri seseorang mengenai apa yang diyakini dan dirasa terhadap hal-hal yang berkaitan dengan cara pengolahan makanan dan minuman yang baik.

Penelitian sikap penjamah di Angkringan kabupaten Barru dilakukan secara langsung, dimana hasil yang didapatkan rata-rata mengatakan setuju dan kurang setuju terhadap pernyataan-pernyataan yang diajukan sehingga dapat tergolong kriteria baik dan kriteria cukup. Hasil ini sejalan dengan penelitian Yahya (2013) bahwa tidak ada hubungan antara sikap penjamah makanan $(p=0,416)$ dengan keberadaan bakteri pada mie basah di lingkungan Universitas Negeri Gorontalo. Sikap penjamah dapat dipengaruhi oleh pengetahuan, rata-rata pengetahuan penjamah di Angkringan tersebut termasuk dalam kategori baik. Hal ini sesuai dengan pernyataan yang dikemukakan oleh Riyanto, (2013) bahwa pengetahuan merupakan salah satu yang memegang peranan dalam menentukan sikap. Faktor lain yang mempengaruhi terbentuknya sikap penjamah yaitu pengalaman pribadi. Menurut Azwar (2011) tidak adanya pengalaman sama sekali dengan suatu objek psikologis cenderung akan membentuk sikap negatif terhadap objek tersebut. Dalam hal ini pengalaman penjamah di Angkringan 
Jurnal Sulolipu : Media Komunikasi Sivitas Akademika dan Masyarakat

Vol. 18 No 22018

e-issn : 2622-6960, p-issn : 0854-624X

kabupaten Barru dapat dikatakan sudah cukup berpengalaman karena para penjamah rata-rata sudah bekerja cukup lama di Angkringan tersebut.

Namun, setelah melihat secara langsung bagaimana cara mengolah minuman yang dilakukan, ternyata responden lebih cenderung kepada sikap yang tidak setuju bahkan ada beberapa responden yang terang - terangan mengatakan tidak setuju dengan pernyataan pernyataan tersebut. Sikap penjamah tersebut menunjukkan kurangnya kepedulian terhadap pengolahan makanan dan minuman yang benar. Hal ini bisa saja disebabkan karena penjamah tidak mengetahui prinsip - prinsip hygiene sanitasi makanan dan kebiasaan penjamah itu sendiri.

Berdasarkan faktor di diatas diketahui bahwa sikap tidak selalu berpengaruh terhadap perilaku seseorang karena sikap merupakan bentuk respon dari suatu stimulus, dimana sikap manusia yang akan menggerakkan untuk bertindak atau berbuat dalam suatu kegiatan dimana dalam bertindak atau berbuat diperlukan adanya niat yang dapat membentuk perilaku seseorang dalam situasi atau kondisi di lingkungan sekitarnya (Utami, 2012). Berdasarkan hal tersebut, maka dapat dikatakan bahwa semakin baik sikap seorang penjamah maka semakin baik pula kondisi sanitasi makanan dan minumannya.

Untuk merubah suatu sikap kita harus ingat bagaimana sikap itu dibentuk. Sikap bukanlah diperoleh karena keturunan tetapi dari teman atau orang lain, pengalaman, dari lingkungan, terutama dari suatu pengalaman yang meninggalkan kesan sangat mendalam. Adapun pengalaman itu menyenangkan maka seseorang akan lebih terbuka dan mudah menerima rangsangan, sebaliknya bila pengalaman tidak menyenangkan maka seseorang akan bersifat tertutup untuk menerima dan mencoba sesuatu yang baru. Dengan demikian, penjamah harus diberikan pemahaman yang mendalam tentang sanitasi pengolahan makanan yang memenuhi syarat dengan menjelaskan tentang dampak yang bisa ditimbulkan akibat sikap yang tidak peduli prinsip sanitasi dalam mengolah makanan.

\section{Hubungan Tindakan dengan Keberadaan MPN Coliform}

Pengetahuan merupakan dasar dari terbentuknya sikap untuk kemudian terwujud dalam bentuk tindakan konkrit. Dari pengetahuan akan terpikirkan apakah sesuatu yang dikenal dapat memberikan keuntungan bagi dirinya atau sebaliknya kerugian yang akan menerimanya sebelum menentukan sikap untuk menerima atau menolaknya. Dan bila diterima akan diwujudkan dalam tindakan konkrit, yaitu melakukan sesuai dengan yang diterimanya.

Berdasarkan hasil penelitian diketahui bahwa ada hubungan antara tindakan penjamah dengan keberadaan MPN Coliform pada minuman yang dijual di Angkringan kabupaten Barru. Hasill ini berdasar pada uji fisher diperoleh nilai $p$ value $0,000(P<0,05)$.

Hal ini didasarkan pada hasil observasi tindakan penjamah yang telah dilakukan terhadap 20 responden di Angkringan kabupaten Barru. Dari 20 responden yang diamati terdapat 7 responden yang memiliki tindakan kriteria baik (40\%) dengan persentase $56 \%$ - 81\% dan 13 responden yang memiliki tindakan kriteria kurang $(60 \%)$ dengan persentase $31 \%-44 \%$.

Hasil penelitian Fitka Romanda (2016) menunjukkan bahwa ada hubungan personal hygiene penjamah makanan dengan keberadaan Escherichia coli pada makanan di Tempat Pengolahan Makanan (TPM) buffer area Bandara Adi Soemarmo Surakarta ( $p=0,000 ; p<0,05)$. Tingkat keeratan hubungan keduanya sedang $(\mathrm{C}=0,477 ; \mathrm{C}<0,5)$. Sedangkan hasil pengujian Dyah Suryani (2014) pengolahan makanan terhadap angka kuman ikan bawal bakar dengan menggunakan pearson chi square adalah sebesar $0.000(p<0,05)$ dan nilai $\mathrm{Cl} 1,940-25,255$ yang tidak mencakup angka 1, artinya ada hubungan yang bermakna antara pengolahan makanan dengan angka kuman ikan bawal bakar.

Menurut Peraturan Menteri kesehatan Republik Indonesia Nomor 942/MENKES/SK/VII/2003 tentang pedoman persyaratan hygiene sanitasi makanan jajanan menyatakan bahwa penjamah makanan jajanan dalam melakukan kegiatan pelayanan penanganan makanan jajanan harus memenuhi persyaratan antara lain tidak menderita penyakit mudah menular (batuk, pilek, influenza, diare, penyakit perut sejenisnya), menutup luka (pada luka terbuka/bisul atau luka lainnya), menjaga kebersihan tangan, rambut, kuku, dan pakaian, memakai celemek dan tutup kepala, mencuci tangan setiap kali hendak menangani makanan, menjamah makanan harus memakai alat perlengkapan, atau dengan alas tangan, tidak sambil merokok, menggaruk anggota badan (telinga, hidung, mulut atau bagian lainnya), serta tidak batuk atau bersin di hadapan makanan jajanan yang disajikan dan atau tanpa menutup mulut atau hidung.

Penjamah makanan (food handler) merupakan sumber utama kontaminasi makanan karena 
Jurnal Sulolipu : Media Komunikasi Sivitas Akademika dan Masyarakat

Vol. 18 No 22018

e-issn : 2622-6960, p-issn : 0854-624X

berperan langsung dalam penanganan makanan, menjaga kebersihan dan keamanan makanan. Hal ini dibuktikan dengan adanya hasil observasi yang menunjukkan bahwa ada penjamah yang mempunyai kuku yang panjang dan kotor selain itu penjamah tidak mencuci tangan sebelum mengolah minuman dan setelah memegang peralatan kotor maupun bahan mentah. Tangan yang kotor atau terkontaminasi dapat memindahkan bakteri dan virus patogen dari tubuh, feces atau sumber lainnya ke makanan.

Cincin juga merupakan benda yang digunakan penjamah sehari-hari sehingga walaupun dicuci dengan air mengalir dan sabun, tetap tidak akan menghilangkan partikel kecil yang tidak terlihat yang menempel pada cincin, dan dikhawatirkan berpindah pada makanan atau minuman pada saat pengolahan. Selain itu perhiasan dapat jatuh ke dalam makanan yang diolah sehingga dapat menimbulkan kontaminasi makanan (Robinson, 2012 dalam Fitka Romanda 2016).

Dengan demikian seorang penjamah harus diberikan penyuluhan tentang bagaimana tindakan yang baik dalam melakukan pengolahan makanan dan minuman yang memenuhi syarat, karena dapat mengakibatkan dampak yang buruk yaitu hasil olahan dapat tercemar baik secara biologi maupun kimia. Perlindungan kontak langsung dengan makanan siap saji dilakukan dengan jalan menggunakan sarung tangan plastik, penjepit makanan, sendok, garpu, dan sebelum sejenisnya. Selain itu, pengolah makanan harus selalu.mencuci tangan bekerja (Arisman, 2009).

\section{Keberadaan MPN Coliform}

Berdasarkan hasil penelitian yang telah dilakukan pada 20 sampel minuman menunjukan bahwa cemaran bakteri Coliform berdasarkan nilai MPN Coliform sampel minuman terdapat 8 sampel yang memenuhi syarat dan 12 sampel yang melebihi batas maksimum yang ditentukan Standar Nasional Indonesia (SNI) tahun 2009 tentang batas maksimum cemaran mikroba dalam pangan bahwa kadar maksimum MPN Coliform dalam sari buah $2 \times 10^{1} \mathrm{koloni} / \mathrm{ml}$. Cemaran bakteri Coliform dapat terjadi karena pada saat penanganan, penggunaan peralatan dan kondisi llingkungan yang tidak hygenis.

Lokasi penjualan minuman yang berada dekat jalan raya menjadi faktor penyebab rendahnya kualitas mikrobiologi pada minuman berdasarkan MPN Coliform koloni bakteri. Berdasarkan hasil observasi diketahui bahwa banyak kendaraan bermotor yang lewat, sehingga mengakibatkan debu-debu dan bakteri terangkat dan mengkontaminasi minuman dan peralatan untuk membuat minuman, sehingga meningkatkan jumlah bakteri pada minuman. Hal-hal tersebut dapat mempengaruhi keberadaan MPN Coliform, sehingga dapat menentukan kelayakan konsumsi minuman tersebut. Ginting dkk (2013) juga menyatakan bahwa dalam hal kondisi lingkungan dapat menyebabkan pencemaran, karena faktor fisik yaitu kondisi lingkungan yang kurang baik, sehingga memudahkan pencemaran bakteri masuk kedalam minuman. Pernyataan tersebut juga diperkuat oleh hasil penelitian Kurniadi (2013), yang menyatakan bahwa lingkungan yang kotor dan tidak terjaga sanitasinya dapat menjadi faktor kontaminasi bakteri pada minuman, contohnya penjual minuman yang berada dipinggir jalan raya, dekat dengan selokan dan banyak terpapar debu asap kendaraan, sehingga berpotensi menjadi sumber pencemaran bakteri patogen.

Nilai hasil rerata MPN Coliform sampel minuman yang dijual di Angkringan tersebut juga berhubungan dengan tindakan penjamah yang rendah tentang pengolahan minuman yang hygiene. Hasil observasi menunjukkan bahwa penjamah kurang memperhatikan sanitasi lingkungan dan personal hygienenya, seperti kebersihan tangan penjamah. Penjamah yang hanya membersihkan tangan dengan lap tanpa mencuci tangan dengan sabun, hal tersebut dapat menjadi salah satu faktor yang menyebabkan kontaminasi bakteri pada minuman karena tangan merupakan salah satu media perpindahan bakteri dari satu orang ke orang lain maupun dari orang ke minuman dan sebaliknya. Hal ini sesuai dengan Agustina (2015) yang menyatakan bahwa bakteri penyebab penyakit dapat ditularkan melalui tangan yang kurang bersih, saat proses persiapan dan penyajian minuman.

Pemilihan bahan baku sangat berpengaruh terhadap keberadaan MPN Coliform dimana berdasarkan hasil observasi beberapa pedagang menggunakan buah yang telah disimpan lama baik didalam refrigerator ataupun disimpan di tempat terbuka, diketahui bahwa $80 \%$ penjamah tidak mencuci buah yang digunakan untuk bahan pembuatan. Selain itu, buah yang sudah dikupas di letakkan di tempat yang terbuka sehingga meningkatkan potensi untuk terjadi kontaminasi oleh bakteri patogen. Pemakaian buah yang tidak segar atau telah busuk mengindikasikan bahwa bahan baku buah yang dipakai dapat terkontaminasi oleh bakteri dan apabila digunakan sebagai bahan dasar jus, sebenarnya dapat membahayakan kesehatan karena buah juga 
Jurnal Sulolipu : Media Komunikasi Sivitas Akademika dan Masyarakat

Vol. 18 No 22018

e-issn : 2622-6960, p-issn : 0854-624X

terkontaminasi oleh bakteri kontaminan. Pedagang yang berjualan di Angkringan masih ada yang menggunakan es balokan yang sumbernya bukan dari tempat yang legal. Hal tersebut dapat menjadi sumber cemaran MPN Coliform karena sumber air yang digunakan pada es balokan bukan dari air yang matang dan tidak memperhatikan hygiene pada saat pengolahan serta pembawaan sampai ke konsumen.

Keberadaan MPN Coliform pada sampel juga disebabkan peralatan yang digunakan dalam proses pembuatan minuman seperti blender, pisau, dan sendok dalam keadaan kurang bersih. Menurut Lalura dkk (2014), penjamah makanan menggunakan peralatan yang tidak bersih dan berulang-ulang serta hanya disimpan di ruang terbuka dapat memacu terjadinya kontaminasi mikroba. Pernyataan ini didukung oleh Faridz dkk (2007) bahwa kotoran yang tertinggal pada peralatan yang tidak bersih, berasal dari sisa makanan yang masih menempel dan debu dari polusi udara akibat penyimpanan peralatan pada ruang terbuka. Diketahui juga bahwa kain lap yang digunakan oleh pedagang untuk membersihkan tangan, blender, pisau dan wadah tersebut adalah kain lap yang digunakan berulang kali. Hal tersebut dapat menjadi salah satu sumber kontaminasi bakteri dalam minuman.

\section{PENUTUP}

\section{KESIMPULAN}

Berdasarkan hasil penelitian ini, dapat disimpulkan bahwa keberadaan MPN Coliform pada minuman di Angkringan kabupaten Barru tidak ada hubungannya dengan pengetahuan ( $p$ value $1,000>0,05)$ dan sikap ( $p$ value $0,373>$
0,05), akan tetapi sangat berhubungan dengan tindakan penjamah itu sendiri, dimana ( $p$ value $0,000<0,05$ ). Hasil pemeriksaan MPN terdapat 12 sampel yang melebihi batas maksimum yang ditentukan Standar Nasional Indonesia (SNI) tahun 2009 bahwa kadar maksimum Coliform dalam sari buah $2 \times 10^{1} \mathrm{koloni} / \mathrm{ml}$.

\section{Saran}

a. Bagi Dinas Kesehatan Kota Barru

Sebaiknya mengadakan dan melakukan upaya peningkatkan pengetahuan tentang hygiene personal penjamah dan sanitasi jajanan, sehingga dapat menghindari penyakit bawaan makanan dan melakukan pengawasan serta pembinaan penjamah untuk meningkatkan kualitas jajanan di Angkringan kabupaten Barru.

b. Bagi Dinas Koperasi, Usaha Kecil, Menengah dan Perdagangan Kabupaten Barru

Sebaiknya menata lokasi angkringan agar tidak terlalu berdempetan dengan jalan dan penyediaan lahan yang memadai khusus parkir kendaraan.

\section{c. Bagi Penjual}

Diharapkan bagi penjamah sebaiknya melakukan perilaku hidup bersih dan sehat misalnya menjaga kebersihan tangan dengan mencuci tangan sebelum pengolahan, menggunakan celemek dan menutup rambut saat pengolahan agar jajanan tidak terkontaminasi, melalui pendidikan secara langsung.

\section{DAFTAR PUSTAKA}

Agustina, F., Pambayun, R \& Febry, F.2010. Higiene dan Sanitasi Pada Pedagang Makanan Jajanan Tradisional Di Lingkungan Sekolah Dasar Di Kelurahan Deman Lebar Daun Palembang. Palaembang: Universitas Sriwijaya. (Jurnal Ilmu Kesehatan Masyarakat)1. http://eprints.unsri.ac.id/64/. Diakses Pada Tanggal 12 Desember 2017

Amalia Pasanda. 2016. Perbedaan Pengetahuan, Sikap dan Perilaku Penjamah Makanan Sesudah Diberikan Penyuluhan Personal Hygiene di Hotel Patra Jasa Semarang. Semarang: Program Studi IImu Gizi Fakultas IImu Keperawatan dan Kesehatan Universitas Muhammadiyah Semarang. (Online).http://repository.unimus.ac.id. Diakses Pada Tanggal 01 Juni 2018.

Arisman.2009.Buku Ajar Ilmu Gizi:Keracunan Makanan. Jakarta : EGC

Azwar, S. 2011. Sikap Manusia Teori dan Pengukurannya Edisi ke-2. Yogyakarta:Pustaka Pelajar. 
Jurnal Sulolipu : Media Komunikasi Sivitas Akademika dan Masyarakat

Vol. 18 No 22018

e-issn : 2622-6960, p-issn : 0854-624X

BPS, 2017. Provinsi Sulawesi Selatan Dalam Angka Sulawesi Selatan Provinsi In Figure. Makassar: Badan Pusat Statistik

Budiman \& Riyanto A., 2013. Kapita Selekta Kuesioner Pengetahuan Dan Sikap Dalam Penelitian Kesehatan. Jakarta : Salemba Medika

Chandra Budiman. 2007. Pengantar Kesehatan Lingkungan. Jakarta: EGC.

Depkes RI. 2009. Klasifikasi Umur Menurut Kategori. Jakarta:Dirjen Yankes.

Dyah Suryani. 2014. Keberadaan Angka Kuman Ikan Bawal Bakar dan Peralatan Makan Bakar. Indonesia: Fakultas IImu Kesehatan Masyarakat Uniersitas Ahnad Dahlan. (jurnal Online). http://journal.unnes.ac.id/nju/index.php/kemas. Diakses Pada Tanggal 01 Juni 2018.

Emida Lusiani BR Meliala. 2017. Perilaku Hygiene dan Sanitasi Makanan Di Tinjau Dari Aspek Penjamah Makanan (Foodhandler) di RC (Retreat Center) Sumakmur. Medan: Jurusan Kesehatan Lingkungan Politeknik Kementerian Kesehatan Medan. (KTI Diterbitkan). http://poltekkes.aplikasi-akademik.com. Di Akses Pada Tanggal 01 Juni 2018.

Faridz, R, Hafiluddin, \& M, Anshari, 2007. Analisis Jumlah Bakteri Dan Keberadaan Eschechia coli Pada Pengelolahan Ikan Teri Nasi PT. Kelola Mina Laut Unit Sumenep. Skripsi, Universitas Trunojoyo, Madura

Fitka Romanda.2016. Hubungan Personal Hygiene Dengan Keberadaan Escherchia Coli Pada Makanan Di Tempat Pengolahan Makanan (TPM) Buffer Area Bandara Adi Soemarmo Surakarta. Surakarta :Fakultas Kedokteran Uniersitas Muhammadiyah Surakarta. (Skripsi Diterbitkan). http:// http://eprints.ums.ac.id. Di Akses Pada Tanggal 1 Juni 2018.

Ginting, W. N. P., Santi, D. N., \& Indra, C. 2013. Hygiene Sanitasi dan Analisa Pencemaran Salmonella Sp. pada Daging Sapi Olahan (Daging Burger) Sebelum dan Sesudah Digoreng yang di Jual di Kelurahan Helvetia. Medan: Departemen Kesehatan Lingkungan Fakultas Kesehatan Masyarakat Universitas Sumatera Utara

Kurniadi, Y, Saam, Z \& Dedi, A. 2013. Faktor Kontaminasi Bakteri Escherichia Coli pada Makanan di Lingkungan Kantin Sekolah Dasar Wilayah Kecamatan Bangkinang. Riau: Universitas Riau. (Jurnal Ilmu Lingkungan) 7 (1): 28-37. https://ejournal.litbang.dep kes.go.id/. Diakses Pada Tanggal 3 Maret 2018

Laura LFH, Lohoo, H \& Hanny, WM, 2014. Identifikkasi Bakteri Escherichia coli pada Ikan Selar (Selaroides sp.) Bakar di Beberapa Resto di Kota Manado.Sulawesi Utara: Universitas Sam Ratulangi . (Online).2 (1) :10-13. https://ejournal.unsrat.ac.id/index. php/jmthp/ article/view/5359. Diakses Pada Tanggal 12 Desember 2017.

Republik Indonesia. 2003. Keputusan Menteri Kesehatan Republik Indonesia Nomor 942/Menkes/SK/VII/2003 Tentang Pedoman Persyaratan Hygiene Sanitasi Makanan Jajanan.

Riyanto Wreksoatmodjo. 2013. Perbedaan Karakteristik Lanjut Usia yang Tinggal di Keluarga dengan yang Tinggal di Panti di Jakarta Barat. Jakarta : Fakultas Kedokteran Universitas Atmajaya.(Online).40. http://kalbemed.com/Portals/6/1_07_209 PerbedaanKarakteristik Lanjut Usia yang Tinggal di Keluarga dengan yang Tinggal di Panti di Jakarta Barat.pdf. Diakses Pada Tanggal 22 Desember 2017.

SNI. 2009. Batas Maksimum Cemaran Mikroba dalam Pangan. http://blog.ub.ac.id/cdrhprimasanti90/. Diakses Pada Tanggal 22 Desember 2017

Soekidjo Notoatmodjo. 2010. IImu Perilaku Kesehatan. Jakarta: PT Rineka Cipta. 
Jurnal Sulolipu : Media Komunikasi Sivitas Akademika dan Masyarakat

Vol. 18 No 22018

e-issn : 2622-6960, p-issn : 0854-624X

Ummu Khairawaty. S. 2013. Perilaku Penjamah Makanan Ditinjau Dari Kualitas Bakteriologis Makanan Jajanan Di Sekolah Dasar Wilayah Kelurahan Mangasa Kec. Tamalate Kota Makassar. Makassar: Prodi D.III Jurusan Kesehatan Lingkungan Poltekkes Makassar (KTI Tidak Diterbitkan).

Utami, N. S. 2012. Kaitan Pencemaran Bakteri Coliform dan Bakteri E.Coli Pada Air Sumur Penduduk dengan Kepadatan Pemukiman di Kecamatan Jebre Kota Surakarta. Surakarta: Universitas Sebelas Maret. (Online). http://jurnal.fkip.uns.ac.id. Diakses Pada Tanggal 01 Juni 2018.

Yahya, J. 2013. Hubungan Perilaku Penjamah Makanan Dengan Keberadaan Bakteri Pada Mie Basah Di Lingkungan Universitas Negeri Gorontalo.Universitas Negeri Gorontal. http://repostory.uneg gor.ac.id/. Diakses Pada Tanggal 22 Desember 2017 